\title{
Differential Analysis of Judicial Proceedings of Crime for Legal Entities
}

\author{
Hassan Ali Moazenzadegan ${ }^{*}$, Behrouz Beigizadeh ${ }^{2 *}$ \\ ${ }^{1}$ Criminal Law, Tehran, Iran \\ ${ }^{2}$ Criminal Law, Allameh Tabataba'i University, Tehran, Iran \\ Email: Moazenzadegan@gmail.com,bbeygizadeh@yahoo.com
}

How to cite this paper: Moazenzadegan, H. A., \& Beigizadeh, B. (2017). Differential Analysis of Judicial Proceedings of Crime for Legal Entities. Open Journal of Political Science, 7, 246-256

https://doi.org/10.4236/ojps.2017.72019

Received: December 6, 2016

Accepted: April 11, 2017

Published: April 14, 2017

Copyright (c) 2017 by authors and Scientific Research Publishing Inc. This work is licensed under the Creative Commons Attribution International License (CC BY 4.0).

http://creativecommons.org/licenses/by/4.0/

cc) (i) Open Access

\begin{abstract}
With an increased number of legal entities, so close competitions were between them and in order to achieve more benefits and stay ahead of competitors, each may fulfill his purpose by any means and in this way, they may not hesitate to even commit illegal and also criminal activities. Gradually, with the maturing of civil claims in relation to legal entities, their criminal responsibility has been discussed. Given that many punishments as well as judicial proceedings of crime which are applicable for individuals are not relevant to legal entities, a form of distinction in proceeding of the crimes of legal entities comes into existence. Differential of the methods of proceedings crimes of legal entities in considering principles of governance in legal entities criminal proceedings is justified by establishing the governance of utilitarian proceedings, dependency of the presumption of innocence, indictment and specialization in judgment. On the other hand, limitation of guarantees of proceedings in criminal proceedings of legal entities due to increase in the period under supervision, lawyer intervention limits in preliminary investigation and territorial expansion, preventive detention, is applicable.
\end{abstract}

\section{Keywords}

Differentiation in the Proceedings, Criminal Responsibility, Procedure Act, Legal Entities

\section{Introduction}

Establishing security and peace in society through bringing offenders to punishment or applying security and corrective arrangements concerning them, is responsibility of the public power which is interpreted as the government. Rules and regulations which must be applied during criminal proceedings, in the 
broad sense, is one of the branches of Criminal Sciences which is called Criminal Procedure. In the past, mostly civil aspects of legal entities were considered and paid less attention to their criminal liability. Iran's judicial system was adopted this approach, but today in most countries, including France, this type of responsibility has been acceptable by some conditions (Abrndabady et al., 2000).

Unlike the former Islamic Penal Code which criminal liability of legal entities had not been considered, in Penal Code adopted in 1392, in addition to penalty of individuals, Iranian legislator deals with legal entities punishment. Unlike the French legal system which knows legal entity's penalties subsidiary to the individual punishment and if the individual is not punished by any reason, penalty of the legal entity will be voided, and article 20 of Islamic Penal Code adopted in 1392 obliges judge to determine one to two of the punishments mentioned in seven paragraphs of the article 20 of this law, in all crimes, in case of confirming criminal liability of legal entities, according to article 143 , whether individual is punishable or not. On the other hand, Procedure Act in Iranian law has no comment about how to do pursuit, investigation, trial and punish the legal entity. Given that many punishments as well as method of proceeding crimes are applicable for individuals that are not suitable for legal entities, a form of differentiation in proceedings of the crimes of legal entities comes into existence which is the subject of this study. In this article, differential of method of proceedings of the crimes of legal entities will be examined by considering various components including: governing of investigating principles of legal entities in criminal proceedings and limitation of proceedings guarantees in legal entities criminal proceedings (Beccaria, 1998).

\section{Literature}

\subsection{Governing of Investigating Principles of Legal Entities in Criminal Proceedings}

Among the principles that justify being differential of legal entities criminal procedure, there are governance of utilitarian proceedings, specialization in judgment, indictment and dependency of the presumption of innocence, these issues will explain and examine in the following paragraphs (Clarkson, 1996).

\section{Governance of Utilitarian Proceedings}

Usefulness index of criminalization is based on the theory of liberal "utilitarianism" which evaluates criminal involvement by cost-benefit analysis. In return, there are theories of moralism which consider the mere violation of ethical rules legitimate, regardless of the results. Though, supporting ethics and moral rules are responsibility of the government, but it cannot be said that every moral principles should be safeguarded (Friedman, 2002).

In the field of public awareness, more than anything else, researches have proved that people have little detailed knowledge about the rules, Criminal Procedure and enforcement (exception to this general rule is about certain groups of offender, particularly in the field of trafficking offenses, tax and economic 
crimes). This simple fact strongly challenges one of the foundations of general prevention, which means, this almost self-evident default that facts relating to the existence of laws, legislative changes, public criminal proceeding and even sentences are being used by people who are expected to stop them (Isfahani, 1950).

Finally the offender should consider the crime loss more than its benefits. The economic model of crime at first was discussed in 1968 by Bentham and Then Becker, American economists. in Becker model, a person who attempts to commit a crime, the possibility of arresting if commit crime and the amount of penalties in the event of arresting and benefits in the event of failure to be arrest are calculated. He commits a crime if the expected benefit of crime be more than disadvantages of its committing and provided that this benefit is more than the benefit which he could have achieved by doing other legal act (Robertson, 2004).

The meaning of loss resulting from the crime is the penalty. However, assessment of the amount of the loss is influenced by three factors:

- The possibility of punishment: although many people just because they are told there is ban, they avoid behavior violates the law, as newcomers to groups and new environments such as school or work that the people do not need to be threaten and it is sufficient to said to them such behavior is prohibited, however, many others fear of punishment. Punishment has a direct relationship with the percentage of crime detection and arresting crimes. When possibility of getting caught decreases, the deterrent effect of punishment is reduced, because people will fear only if people think there is a reasonable probability of their arrest (Khazani, 2001).

\subsection{The Intensity of Punishment}

A deterrent penal system should regulate and determine the amount of punishment fit to exercise its deterrent program. So, it is not like that the more severe punishment, the more deterrent as well. Nevertheless, punishment intensity index changes are far less effective to strengthen one of the reliability and certainty reasons of one to certainty of punishment (Mahmoudi, 2006).

Here, the classical utilitarian theory default according to which any weakness at risk of being arrest can be compensated by increasing the intensity of punishment and gained the same amount of inhibition has been challenged.

Experimental researches show that considering all the issues, subjective certainty of punishment which is one of the functions of perception discover risk, in relation to perceived intensity of punishment, has more important role in deterrence pattern. Intensity of punishment be paid attention just when discovery risk be taken serious and only in this way, there is the intensity towards a form of rational calculation of pleasure against suffering (profits results of crime against its cost).

\subsection{Speed in Penalties}

This is a classic finding that the rate of delay in response to behavior that violated the law, effects of deterrent penalties is reduced, because people valorize 
less for incoming events compared with now events, whether they will be pleasant or unpleasant. Bentham as a pioneer of utilitarianism considered closeness and farness as a key factor in the calculation of pleasure and pain. Also, Beccaria knew speed is very useful in criminal enforcement. He believed if the time is shorter between crime and punishment, evoke of two concepts of crime and punishment in human's mind is stronger and more stable so that human considered one is effect and another is imperative and necessary caused, gradually.

On the other hand, the same factors that are involved in detecting the loss of punishment as well as benefits of crime detection are effective, including;

1) The urgency for obtaining the benefits: Deposit the losses obtained of punishment, which the holding the trail title is usually associated with delay, the benefits obtained of crime in many crimes is immediate, or very close to the time of the crime. Benefit of most crimes that called conditioned to result in criminal law, is obtained immediately following the crime, in contrast, crimes so-called absolute, because of the realization of a crime and to punish the offender do not need result and these results are generally the same purpose of committing a crime, as a result, either their benefit isn't in punishment or it is necessary some crime to punish them. Also, in crimes so-called incomplete can be seen this same situation. It isn't necessary to achieve total crime for punishing the offender in these crimes too, so its loss obtains earlier. Of course, all of them are true, if the consideration related to merit and justice does not prevent of same punishment of complete or incomplete crimes, otherwise less punishment of incomplete crime compensates its urgency because of severity of injury to guilty is lower. So it may be claimed that increasing in complete and incomplete crimes in criminal laws can have a positive effect on criminal deterrence, because it does not chance to offender for profiting to punish him, otherwise, conditioned and complete crime, the criminal justice system draws a figure of a threat associated with delay against an urgent appeal to benefits of crime.

2) The certainty for obtaining the benefits: the urgency in obtained benefits of crime also affects on its certainty, in other words, there is a direct relationship between urgency and certainty, the possibility of occurring disturbing events that effect on its certainty will be decreased, when this benefit obtains sooner. Nevertheless, it is possible the authorities avoiding the immediate benefit by castrate its certainty with creating obstacles.

3) The value of benefits: The purpose of benefits is the motivation, stimulus or the same feeling of satisfaction that offender crime to obtain it. These motivation are more taken from the natural human needs which followed through illegal ways, revenge, satisfying the sexual desires, accumulating wealth and greater incentives such as aiding to the fellowman, avoiding the discrimination and oppression from society and so on. To the preventive punishment, It should be attempted the value of punishment for offender can be equal by value of urgency and certainty of crime, by accounting the delay.

\subsubsection{Dependency of the Presumption of Innocence}

The presumption of innocence is the kinds of practical principles that deter- 
mines the practical task of obliged person about cases which he suspects in actual tasks after searching and lack of causes, and decrees of innocence to him in the dubious task; in other words, the presumption of innocence, as one of the practical principles is perform when there is doubt and lack of access to religious justification, and in practice, it does not obligated the obliged person to perform the task; for example, after searching and lack of reason, the obliged person suspects of permissibility and illegality of smoking, the presumption of innocence is performed and decreed to permissibility of using it and finally he is protected of the possible opposition with the actual sentence.

So, if, after the search of reason and lack of access to it, one doubted in duty, the duty would not prove to be the responsibility of the obliged; that is, in question of obligation, leave it, and in question of sanction, commit it is permissible; the origin of doubt, the lack of text, summary of it or conflict between two texts do not matter. operation place of the presumption of innocence is doubt in duty and this doubt, Sometimes caused by Doubt in the verdict (judgment doubt) and sometimes from Doubt in the subject (subject doubt) and judgment doubt, Sometimes is obligatory and sometimes is sanctions and the source of doubt in judgment doubt, Sometimes is the lack of text, Sometimes is Summary of text and sometimes is conflict between two texts (Mohseni, 2012).

The presumption of innocence which explains and ensures good will toward other's social behavior and avoids distrust of the people and respect for legitimate freedoms and protect civil rights is not limited to stage of proceedings and sentencing; but it also contains police preliminary investigation stage and law enforcement, prosecution and crime detection in court.

What arises regarding the presumption of innocence is limitation and territory of this principle. Executive territory of the criminal presumption of innocence in addition to its effects in civil and criminal proceedings, can be observed in two approaches, one the cultural, and the other legal and practical approaches which in the following briefly the two approaches and limitation territory of the presumption of innocence are mentioned; one is the of cultural and subjective territory of presumption of innocence and the other is the presumption of innocence in fact and one of the important cultural values and moral and even necessary of human community.

Despite the position of presumption of innocence in criminal matters and its ruling on the principles and the rules of criminal law, in certain cases, the application of this principle is avoided. In such cases, while the principle was presumption of innocence and it is the duty of prosecution to prove legal elements of the crime and accused is not obliged to prove his innocence, the burden of proof has changed and it would be responsibility of the accused.

Basis of avoidance of the presumption of innocence in many cases is the same basis that justifies the rule of presumption of innocence in criminal cases. In other words, as legal justice will require in the absence of reason, presumption and innocence of the accused will be sentenced, in certain cases, there are evidences that reinforces suspicion of committing a crime by accused, due to legal 
justice and public interests, and priority of circumstantial evidence of criminality is on the presumption of innocence.

Avoidance of the presumption of innocence will be rationalized in case that there would be legal or judicial circumstantial evidence which cause strong suspicion or is ensuring, and the existence of the circumstantial evidence changes proceedings and in this way, the presumption of innocence in relation to accused has been vanished and as a result, despite the lack of conclusive reason, the judge appeals proceedings exceptional methods. Basis of avoidance of the presumption of innocence in many cases exactly is the same basis that justifies the ruling of presumption of innocence in criminal matters.

In certain cases which the existence of suspicion counterparts strengthen committing crime by accused, due to legal justice and general materials, the priority of circumstantial evidence of criminality is to the presumption of innocence. So in case of avoidance of the presumption of innocence, proceedings would appeal exceptional methods. In these methods, burden of proofing reason was displaced and by priority of circumstantial evidence of criminality to the presumption of innocence, proof of presumption of innocence would consider as the responsibility of the accused (Naini, 1999).

Cases of avoidance of the presumption of innocence are considered as a basic principle governing the law. These cases mainly considered in areas that firstly, committing crime caused severe damage to society or a serious threat considered against it and secondly, proving crime by the attorney general and prosecution due to the particular complexities of committed crime is not possible. In such cases, to real criminals not be able to get away of the administration of justice, the circumstantial evidence of criminality is preferred to the presumption of innocence.

\subsubsection{Indictment}

One of the important points in the field of criminology, criminal law, and legal entities including corporate crimes, is contrast and difference between the concept of crime in the field of criminology and criminal law, under the influence of the principle of legality of offenses and punishment. According to the structure, nature and objectives of these crimes, corporate offenders while avoiding violence and heavy acts, in order to achieve their criminal goals, using their good looks and social status, appeal the types of deceitful or unethical actions which may not be criminalized. This point is considered as one of the difficulties in identifying the perpetrators and obstacles in the pursuit and trial.

According to what was said, there are many theoretical and practical differences between crimes of legal entities and other types of criminal activity. The result of comparing the different aspects of this crime together, are notes that as features of the crime of legal entities make possible differentiate and distinguish them from classic crime. The most important of these tips include:

1) The crimes are often carried out in secret.

2) The offenders of crimes of legal entities (similar to white-collar crime), usually are in the scene somehow legitimately. 
3) These crimes compeer abuse of trust associated with their position or professional.

4) Committing these crimes are often compeer knowledge of interior trusted staff of organization.

5) Usually after committing the crime of legal entities, there is no plaintiff Otherwise, complain are long time after the crime occurrence.

6) Due to lack of physical threats and violence, crimes of legal entities in compare to other crimes are less a source of fear and concern.

7) Due to the nature and organizational structure and existed challenges in issues of criminal liability of legal entities, determination criminal liability and the ability to assign it may be very difficult.

8) In general, crimes of legal entities (such as white collar crime), have ambiguous legal and criminal status.

One of the cases where crime will be announced is victim complaint of crime. Crimes of legal entities often contain the vast negative effects in micro and macro levels. The scope of the consequences is spread of the economic impact on health to disrupt the performance of companies and organizations and their employees, decline in the value of stock and bonds, crimes related to bank loans, undermine investor confidence and the loss of personal investment and even harms suffered to those who lose their saving and few personal assets. It is therefore possible that range of impact of committed crime spreads to the point of disrupting the country's economic system (Palmer, 2000).

\subsubsection{Specialization in Judges}

The specialization of courts has no relation to the laws and regulations because the formation of laws is in the context of legislative duties and courts are one of the users of laws. Therefore, linking amount of deterrent punishment such as execution to subject of specialization of courts seems not to be correct. There is a difference among ordinary crimes and crimes of legal entities. Given that crimes of legal entities has a public character and include the interests of various entities, the difference is clear and the above-mentioned addressing the crimes needs specialty of judge (Motahari, 1999).

Specialized courts with the specialized judges have a lot of benefits. in these courts, judges due to have high experience and expertise in matters relating to legal entities crimes, judges in relation to general court have adopted practical decisions and sentence documentary and useful votes in support of victims of legal entities crimes and preventing violation of their rights, this expertise is very important for which more issues related to crimes of legal entities need detailed technical information.

The way of interpreting and inferring of specialized courts in comparison to unspecialized courts is coordinated with the requirements of legal entities crime. to minimize time investigation process while performing an accurate proceedings and making proper decision which are important goals in all resolution mechanisms at domestic and international level, will be better realized through specialized courts. 
Familiarity of judges to investigation patterns and limited and repetitive subjects increase their speed. Besides that, risks of mistake in decision-making also reduce. Achieving these objectives in legal entities crime is critical and important. Reducing processing times in addition to saving time reduce costs of courts and their administrative staff. In specialized courts, private parties of a disagreement mention their disagreement with more desire and confidence. In countries where specialized courts have been established, this issue will have a significant impact on encouraging foreign investment and it is considered as enterprise development factors. In such cases, the parties in the case, in case of ensuring of the procedure quality, prefer to resort to them to resort to other sources.

In addition to all the benefits mentioned above, the development of specialized courts in the world can create uniform procedures and accelerate the harmonization processes of dispute resolution related to legal entities crimes. Some juristic have suggested that to help achieve this important goal, it's better to create a joint database of all the specialized courts in the world, through which the courts can convey their skills and experience to each other. the opinions issued by the courts was published with professional secrecy parties, through the mentioned base to gradually in national systems of the conflict judgment prevent sentence the opponent votes in the topics similar to the common rules.

\subsection{Limiting of Proceedings Guarantees in Criminal Procedure of Legal Entities}

Considering that legal entities crimes with the nature of the risk against public are occurring, of course, they are excluded of the minimum granting of proceedings. Although Iran's laws in this area has not a different and systematic approach, but French law in this area has shown deliberate legislative measures.

\subsubsection{Increasing the Period of Monitoring}

Among the measures that is considered essential and important to progress of the investigation, is monitoring the individual who here is likelihood of committing crime. If in the context of Iran's Code of Criminal Procedure, the term "monitor" is little used, rules Related to "monitor" in France Criminal Procedure Code had several developments.

Some legal authors suggested two reasons for cause of increasing the monitoring time for terrorist crimes: first, because terrorist crimes are usually committed in a complex way and secretly, with tools and general rules, effective action in this area cannot be done; therefore, increased monitoring time for a closer look to identify other factors is essential; another reason is that because the crime are often took place organized and in an international dimension, in some cases the need to take other features including the use of translators to conduct interrogations will be required more time.

\subsubsection{Restriction of Lawyer Intervention in Preliminary Investigations} Cooperating of lawyer in preliminary investigations is valuable due to ensure defending rights of accused; thus, in many countries, the lawyer has an active 
and effective role in preliminary investigation phase as well as proceeding phase.

In new reformation, French legislative has not change exceptions in the field which has accepted about some important crimes; thus, article 63-4 of France criminal proceeding act states that whenever doing monitoring related to crimes is caused by mentioned organized groups in articles 2-5-224 and 9-311 of the French Penal Code or associated with mentioned offenders community misdemeanor in article $1-450$ of the same law, lawyer can meet his client possibility would be subject to the passage of 48 hours since the beginning of monitoring time.

Acceptance of previous exceptions in the new reformation of the criminal procedure code shows that legislator has retained his special attitude upon security charges and new reforms which since the beginning of the investigation, have been developed in order to benefit the monitoring person of the guarantee of the rights of defense, only include general crimes (Reesi, 2005).

\subsubsection{Development of the Territory of Preventive Detention}

Preventive detention or temporary detention, which is referred as severest safeguarding has got special status in the criminal procedure code because of being in line with benefits such as prevent escape or hiding of the accused, avoid the effects of crime destruction and the prevention of collusion with other persons on the one hand and also because of conflict with the presumption of innocence, the impact on the fate of criminal proceedings, professionalize detainees and create additional costs to the government on the other hand. This equilibrium point due to the new approach of countries and international and regional documents is efforts to limited benefit of this provision of the criminal safeguarding and assign it to a last resort. French law using of replacement decision such as decision of "judicial control" that from 1970 is added to French law and the limitation of the powers of interrogator in issuing the temporary detention will be evaluated in this regard by creation of the new judge as "the judge of freedoms and detention" which is of the greatest innovations of law of June 15, $2000 \mathrm{ad}$. At the same time, checking the rules on safeguarding appointments of countries shows that in serious crimes and particularly in offenses against public safety, countries urge to use this type of safeguard (Mozafar, 1970).

Current regulations ruling on temporary detention in Iranian law and French show that the two countries among the available methods in exercising judicial authority in issuing the temporary detention have used the method of "detention time limit along with the possibility of extending of its successive". In this way, legislator without considering a period for ending preliminary investigation, limit term detention and oblige reference issuing appointment to extend detention for the same period or more than it after spending legal time and in case of non-completion of the preliminary investigation, by justifiable reasons.

\section{Conclusion}

In conclusion of expressed content, the following results can be presented: 
1) The principles which justify criminal procedure of the legal entities differential, are rule of utilitarian procedure, specialization of judges, the indictment and the presumption of innocence.

2) The purpose of obtained losses from crime is the punishment. Although the assessment of the amount of the loss is influenced from following three factors: possibility of punishment, intensity of punishment and speed of punishment.

3) The presumption of innocence requires that a court or tribunal presents the reasons related to legal, material and moral element and attributing the crime to the defendant and in all cases, being expressed inability to reason, it assumes the accused is innocence if it cannot present reasons. Considering the benefits of society has caused lawmakers in these cases such as crimes of legal entities, departing from this principle, and ignoring its results and defendant is saddled with proofing reasons of one of the elements of crimes.

4) The important points in the field of criminology, criminal law of legal entities, including corporative crimes, contrast and difference between the concept of crime in the field of criminology and criminal law, are influenced by legality of crimes and punishments. According to the structure, nature and objectives of such crimes, corporative criminals resort to variety of unethical or fraudulent acts by using their warranted figures and social status while avoiding violence and heavy acts, in order to achieve their criminal objectives, where it may not been criminalized.

5) Specialization of courts is not related to how to legislate since the formation and adoption of laws are within the framework of the duties of the legislature and courts are one of the laws users. Therefore, making link between the inhibition rates of execution and specialized subjects of courts does not seem correct, because there are differences between ordinary crimes and crimes of legal entities.

6) Limitation of procedure guarantees in criminal procedure of legal entities can be increased stake outing time, limits in attorney's intervention in the preliminary investigation of the realm of practical preventive arrest.

\section{References}

Abrndabady, N., Ali, H., \& Beigy, H. M. (2000). Encyclopedia of Criminology. Tehran: Shahid Beheshti University Press.

Beccaria, S. (1998). Treatise of Crimes and Punishments. Translated by Mohammad Ali Ardebili, Tehran: Shahid Beheshti University Press.

Clarkson, C. M. V. (1996). Analysis of the Principles of Criminal Law (2nd ed.). Translated by Hossein Mir Mohammad Sadeghi, Tehran: Shahid Beheshti University Press.

Friedman, L. (2002). Deterrence. Translated by Asgar Ghahreman Pour Bonab and Talebi Arani, R., Tehran: Center for Strategic Studies Press.

Isfahani (1950). Mohammad Taqi Ibn Abdul Rahim. Qom: Hdayh Almstrshdyn Fi Malm as al-Din al-Islami House Institute.

Khazani, M. (2001). Presumption of Innocence and Adducing in the Criminal Cases. The Journal of Legal Studies, No. 14 and 15.

Mahmoudi, F. (2006). Criminalization of Legal Topics in Iran and the Influence of Social and Political Considerations on It. The Journal of Religion and Communications, No. 
17.

Mohseni, F. (2012). Corporative Crime from the Perspective of Criminology. Perspectives of Criminal Justice Journal, No. 57.

Motahari, M. (1999). Introduction to Islamic Sciences. No. 3, Bakersfield, CA: Sadra Press.

Mozafar, M. R. (1970). Al-Fiqh Principles (Vol. 2). The House Vsshal Altabh Ljmah Almdrsyn Logwood.

Naini, M. H. (1999). The Benefits of Principle (Vol. 3). Qom: The Society of Seminary Teachers of Qom.

Palmer, M. (2000). Ethical Issues. Translated by Ali Reza Al-Buwayh, Qom: Ganj-e-Danesh Press.

Reesi, L. (2005). Study of Specialized Courts for Intellectual Property Rights. Mofid Magazine, No. 64.

Robertson, J. B. (2004). Law Commission of New Zealand. Report No, 85 Justice for All.

Submit or recommend next manuscript to SCIRP and we will provide best service for you:

Accepting pre-submission inquiries through Email, Facebook, LinkedIn, Twitter, etc. A wide selection of journals (inclusive of 9 subjects, more than 200 journals)

Providing 24-hour high-quality service

User-friendly online submission system

Fair and swift peer-review system

Efficient typesetting and proofreading procedure

Display of the result of downloads and visits, as well as the number of cited articles

Maximum dissemination of your research work

Submit your manuscript at: http://papersubmission.scirp.org/

Or contact ojps@scirp.org 